\title{
Faktor Yang Mempengaruhi Tax Avoidance Pada Perusahaan Barang Konsumsi Yang Terdaftar Di BEI
}

Tax Avoidance and Consumer's Goods Manufactures

\author{
Desy Mariani \\ Program Studi Akuntansi, Universitas Budi Luhur \\ Jakarta, Indonesia \\ E-Mail: desy.mariani@budiluhur.ac.id
}

\begin{abstract}
This research is conducted to analyze the influence of liquidity, leverage, sales growth and capital intensity of tax avoidance. The population in this research is used secondary data from the financial statement of sub sector good consumer companies listed in the Indonesia Stock Exchange in 2014 2018 as many as 48 companies. This research used purposive sampling method and obtained 24 companies for sample. The data analysis used double linear regression analysis with program SPSS version 20. The result of this research show that sales growth have positive effect on tax avoidance. While liquidity, leverage and capital intensity have not effect on tax avoidance.
\end{abstract}

Keywords: Tax avoidance, liquidity, leverage, sales growth, capital intensity.

\section{PENDAHULUAN}

Dalam pelaksanaan pembangunan, pajak merupakan penyumbang pendapatan negara terbesar untuk membiayai semua pengeluaran demi terwujudnya kemakmuran rakyat. Pajak menurut UU No. 16 tahun 2009 tentang perubahan keempat atas UndangUndang nomor 6 tahun 1983 tentang Ketentuan Umum dan Tata Cara Perpajakan adalah kontribusi wajib kepada negara yang terutang oleh orang pribadi atau badan yang sifatnya memaksa,dan tidak mendapat imbalan secara langsung serta digunakan untuk keperluan negara. Peranan pajak semakin besar dan signifikan dalam menyumbang penerimaan negara, hal ini dapat dilihat dari terus meningkatnya pendapatan pemerintah dari pajak dalam APBN, yang selanjutnya digunakan untuk membiayai penyelenggaraan pembangunan maupun untuk biaya rutin negara. Untuk itu perlu diupayakan peningkatan kesadaran dan kepedulian masyarakat dalam membayar pajak.

Salah satu pihak yang memberikan kontribusi besar dalam penerimaan pajak adalah entitas bisnis atau perusahaan, namun tujuan pemerintah untuk memaksimalkan penerimaan pajak seringkali bertentangan dengan tujuan perusahaan sebagai wajib pajak. Usaha untuk mengatur jumlah pajak yang harus dibayarkan merupakan hal yang harus dilakukan oleh wajib pajak. Pajak juga tidak memberikan imbalan secara langsung kepada wajib pajak, sehingga timbul keinginan wajib pajak meminimalkan beban pajaknya agar dapat memaksimalkan labanya. Berusaha mengurangi pajak terutang dengan mencari kelemahan yang terdapat dalam peraturan tidak bias dikatakan melanggar peraturan perpajakan oleh karena itu tax avoidance tidak bisa dikatakan melanggar peraturan perpajakan (Pohan, 2018).

Banyaknya praktik penghindaran pajak yang dilakukan oleh perusahaan dapat dibuktikan pada tahun 2016 yaitu terdapat sekitar 2.000 perusahaan multinasional yang beroperasi di Indonesia tidak membayarkan Pajak Penghasilan (PPh) Badan Pasal 25 dan Pasal 29 karena alasan kerugian, tetapi perusahaan tersebut sebenarnya masih eksis. Perusahaan asing yang melakukan penghindaran pajak tersebut selama 10a tahun adalah tidak membayarkan kewajiban pajaknya dengan mengalihkan keuntungan/laba

\section{JIAKES}

$$
\begin{array}{r}
\text { Jurnal Ilmiah Akuntansi } \\
\text { Kesatuan } \\
\text { Vol. } 8 \text { No. 3, 2020 } \\
\text { pg. 253-262 } \\
\text { IBI Kesatuan } \\
\text { ISSN 2337 - 7852 } \\
\text { E-ISSN 2721 - 3048 }
\end{array}
$$


Tax Avoidance and Consumers Goods Manufactures perusahaan dari Indonesia ke negara lain atau dapat juga disebut transfer pricing. (www.bisnis.liputan6.com).

Oleh karena itu, untuk meminimalisir tindakan penghindaran pajak yang dilakukan oleh wajib pajak, Direktorat Jendral Pajak memberlakukan peraturan untuk mengantisipasinya. Nugroho (2009) menyatakan bahwa terdapat peraturan berdasarkan Pasal 18 UU Pajak Penghasilan yang digunakan untuk mengantisipasi skema-skema penghindaran pajak di Indonesia yang dinamakan anti avoidance rules. Peraturan inilah yang menjadi acuan legal tidaknya suatu tindakan penghindaran pajak. Tindakan penghindaran pajak dikatakan legal dan diperbolehkan bila wajib pajak tidak menyalahi peraturan tersebut. Hal inilah yang membuat penulis tertarik untuk mengkaji penelitian mengenai faktor-faktor apa saja yang mempengaruhi dalam tax avoidance maka diperlukan penelitian lebih lanjut. Beberapa faktor yang dapat mempengaruhi terjadinya tax avoidance disuatu perusahaan diantaranya adalah likuiditas, leverage, sales growth, dan capital intensity.

Likuiditas merupakan rasio yang menunjukkan kemampuan perusahaan dalam memenuhi kewajiban atau membayar hutang jangka pendeknya (Hery, 2015). Likuiditas sebuah perusahaan diprediksi akan mempengaruhi agresivitas pajak perusahaan (Anita, 2015). Perusahaan dengan rasio likuiditas yang tinggi menunjukkan tingginya kemampuan perusahaan dalam memenuhi hutang jangka pendeknya, yang menandakan bahwa perusahaan dalam kondisi keuangan yang sehat. Dalam kaitannya dengan pajak, perusahaan yang memiliki tingkat likuiditas tinggi menggambarkan bahwa perusahaan memiliki arus kas yang baik sehingga perusahaan berani untuk membayar seluruh kewajibannya termasuk membayar pajak sesuai ketentuan yang berlaku. Beban bunga yang tinggi akan memberikan pengaruh berkurangnya beban pajak perusahaan (Permata, et al, 2018). Semakin besar hutang maka laba kena pajak akan menjadi lebih kecil karena insentif pajak atas bunga hutang semaking besar (Darmawan \& Sukartha, 2014). Penelitian Salaudeen dan Eze (2018) menunjukkan bahwa leverage memiliki pengaruh terhadap tax avoidance.

Menurut Dewinta dan Setiawan (2016) pertumbuhan penjualan (sales growth) memiliki peranan yang penting dalam manajemen modal kerja karena dapat menggambarkan baik atau buruknya tingkat pertumbuhan penjualan suatu perusahaan dan perusahaan dapat memprediksi seberapa besar keuntungan yang akan diperoleh dengan besarnya pertumbuhan penjualan. Apabila sales growth mengalami peningkatan, perusahaan akan cenderung mendapatkan keuntungan yang besar, oleh karena itu perusahaan juga akan menimbulkan beban pajak yang besar pula. Hasil penelitian Dewinta dan Setiawan (2016) menyatakan bahwa sales growth berpengaruh terhadap tax avoidance. Sedangkan penelitian Permata, et al. (2018) menyatakan bahwa sales growth tidak berpengaruh terhadap tax avoidance.

Capital intensity menggambarkan banyaknya investasi perusahaan terhadap asset tetap perusahaan Dharma dan Noviari, (2017). Kepemilikan aset tetap yang besar dapat mengurangi pembayaran pajak, karena aset tetap memiliki beban depresiasi atau beban penyusutan yang dapat dijadikan sebagai pengurang pajak. Hal ini menunjukkan bahwa perusahaan dengan tingkat aset tetap yang tinggi memiliki beban pajak yang lebih rendah dibandingkan perusahaan yang mempunyai aset tetap yang rendah. Perusahaan yang lebih menekankan pada investasi berupa aset tetap akan memiliki tarif pajak efektif yang rendah. Hal tersebut sejalan dengan hasil penelitian Dharma dan Noviari (2017) dan Anindyka, Pratomo dan Kurnia (2018) yang menyatakan bahwa capital intensity berpengaruh terhadap tax avoidance. Semakin besar intensitas aset tetap dalam suatu perusahaan, maka semakin besar pula kecenderungan praktek tax avoidance karena adanya peluang bagi manajer untuk memanfaatkan adanya aset tetap perusahaan dalam memperoleh pengurangan besaran pajak. Tetapi hasil penelitian Wiguna dan Jati (2017) berbanding terbalik yang menyatakan bahwa tidak adanya pengaruh antara capital intensity dengan tax avoidance. 
Pada penelitian yang membahas faktor yang mempengaruhi Tax Avoidance telah beberapakali dilakukan sebelumnya namun hasilnya masih beraneka ragam. Dalam penelitian ini variabel yang diuji hanya variabel terkait keuangan saja Tujuan dilakukannya penelitian ini yaitu untuk mengetahui apakah ada pengaruh likuiditas, leverage, sales growth, dan capital intensity terhadap Tax Avoidance pada perusahaan Sub Sektor Barang Konsumsi yang terdaftar di Bursa Efek Indonesia (BEI). Adapun periode penelitian yang digunakan adalah periode 2014-2018.

\section{METODE PENELITIAN}

Populasi yang digunakan dalam penelitian adalah seluruh perusahaan sub sektor barang konsumsi yang terdaftar di Bursa Efek Indonesia periode 2014-2018 berjumlah 48 perusahaan. Metode penentuan sampel dengan purposive sampling method, diperoleh 24 sampel perusahaan yang diteliti dengan kriteria sebagai berikut :

Tabel 1. Ringkasan Perolehan Data Sampel Penelitian

Kriteria Jumlah Perusahaan

Perusahaan sub sektor barang konsumsi yang terdaftar di BEI pada tahun 2014-2018

Perusahaan yang tidak menerbitkan laporan keuangan secara lengkap selama periode 2014 - 2018 dan perusahaan yang melakukan Initial Public Offering(IPO) di Bursa Efek Indonesia pada periode 2014- 2018. Perusahaan yang mengalami kerugian dan tidak memiliki beban pajak selama periode $2014-2018$.

Jumlah perusahaan sampel

Jumlah data sampel (24 perusahaan x 5 tahun periode pengamatan)
Tax Avoidance

and Consumers

Goods

Manufactures

Sumber: $w w w . i d x . c o . i d$ diolah oleh penulis

Penelitian ini menggunakan teknik dokumentasi dalam memperoleh data yang digunakan. Data diperoleh dari laporan keuangan dan laporan tahunan dengan mengakses website $w w w$.idx.co.id .

\section{Pengembangan Hipotesis}

Pengaruh Likuiditas Terhadap Tax Avoidance. Perusahaan yang memiliki rasio likuiditas yang cukup tinggi menggambarkan pula perusahaan tersebut mampu membayar kewajiban jangka pendeknya, sehingga perusahaan dapat dikatakan dalam kondisi keuangan yang baik. Dalam perusahaan yang memiliki tingkat likuiditas tinggi menggambarkan bahwa perusahaan memiliki arus kas yang baik sehingga perusahaan berani untuk membayar hutangnya termasuk membayar pajak sesuai ketentuan yang berlaku. Begitupun sebaliknya, jika perusahaan memiliki tingkat likuiditas yang rendah maka arus kas perusahaan pun akan rendah, tingkat likuiditas yang rendah ini diakibatkan karena hutang lancar lebih besar dibanding aktiva lancar, hal ini akan menyebabkan perusahaan takut atau tidak taat dalam membayar pajak guna mempertahankan arus kas perusahaan dari pada harus membayar pajak. Sejalan dengan penelitian Budianti dan Curry (2018) menunjukkan bahwa likuiditas berpengaruh positif terhadap tax avoidance. Dari uraian diatas, dapat disimpulkan hipotesisnya adalah:

\section{$\mathrm{H}_{1}$ : Likuiditas berpengaruh positif terhadap tax avoidance.}

Pengaruh Leverage Terhadap Tax Avoidance. Leverage dapat diukur dengan rasio Debt to Equity Ratio (DER) yaitu membandingkan antara total hutang perusahaan dibagi dengan total ekuitas. Artinya, seberapa besar beban hutang yang harus ditanggung perusahaan untuk menghasilkan modal bagi perusahaan. Semakin tinggi nilai leverage, semakin tinggi biaya pendanaan hutang yang berasal dari pihak ketiga yang dipakai perusahaan sehingga semakin tinggi pula biaya bunga yag berasal dari hutang tersebut. Biaya bunga yang meningkat akan memberi dampak yaitu berkurangnya beban pajak perusahaan. Hal tersebut memicu kemungkinan perusahaan melakukan tax avoidance. Hal ini sejalan 
Tax Avoidance and Consumers Goods Manufactures

\section{6}

dengan penelitian Kimsen, Kismanah dan Masitoh (2018) yang menyatakan bahwa leverage berpengaruh positif terhadap tax avoidance. Dari uraian diatas, dapat disimpulkan hipotesisya adalah:

\section{$\mathrm{H}_{2}$ : Leverage berpengaruh positif terhadap tax avoidance.}

Pengaruh Sales Growth Terhadap Tax Avoidance. Sales growth atau pertumbuhan penjualan merupakan perubahan tingkat penjualan pada laporan keuangan per tahun yang dapat mencerminkan prospek perusahaan dan profitabilitas dimasa yang akan datang. Apabila sales growth mengalami peningkatan, perusahaan akan cenderung mendapatkan keuntungan yang besar, oleh karena itu perusahaan juga akan menimbulkan beban pajak yang besar pula. Besarnya beban pajak yang ditimbulkan dari tingginya tingkat penjualan menyebabkan perusahaan memiliki kecenderungan yang besar untuk melakukan tax avoidance agar pajak yang dibayarkan berkurang. Hal ini sejalan dengan penelitian dari Dewinta \& Setiawan (2016) yang menngatakan sales growth berpengaruh positif terhadap tax avoidance.Berdasarkan uraian diatas, maka dapat disimpulkan hipotesisnya adalah :

\section{$\mathrm{H}_{3}$ : Sales growth berpengaruh positif terhadap tax avoidance.}

Pengaruh Capital Intensity Terhadap Tax Avoidance. Capital intensity meggambarkan seberapa banyak investasi perusahaan dengan asset tetap perusahaan. Perusahaan memotong pajak sebagai akibat adanya penyusutan aktiva tetap setiap tahunnya hal ini disebabkan aset tetap yang dimiliki perusahaan. Perusahaan yang memiliki proporsi dalam asset tetap yang lebih tinggi maka pajak yang dibayarkan akan lebih rendah, dikarenakan perusahaan yang memperoleh keuntungan yang berasal dari depresisasi yang melekat pada asset tetap yang berakibat pada pengurangan beban pajak perusahaan. Semakin tinggi intensitas aset tetap dalam suatu perusahaan, maka semakin besar pula kecenderungan praktek tax avoidance. Hal ini sejalan dengan penelitian Anindyka, et al (2018) yang menyebutkan bahwa capital intensity berpengaruh positif terhadap tax avoidance. Berdasarkan uraian diatas, maka dapat disimpulkan hipotesisnya adalah:

\section{$\mathrm{H}_{4}$ : Capital intensity berpengaruh positif terhadap tax avoidance.}

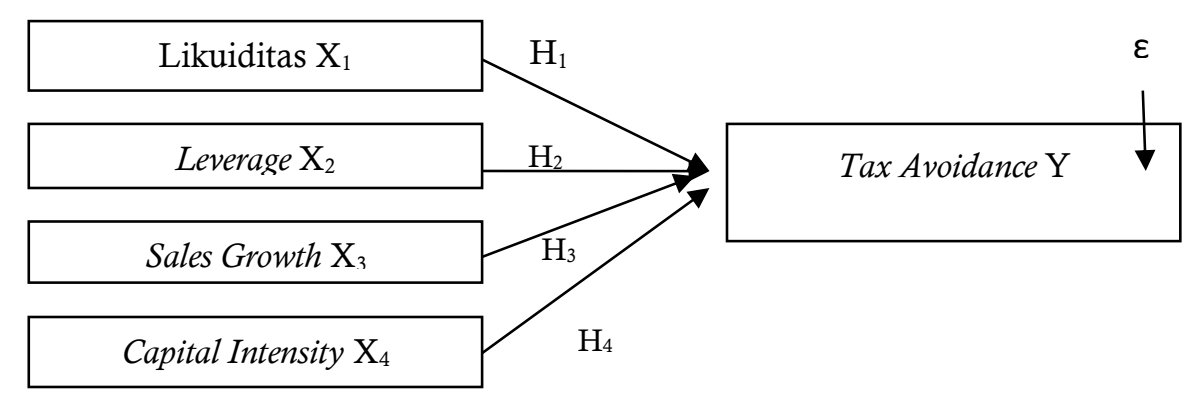

Gambar 1. Kerangka Teoritis Penelitian

Tabel 2 : Operasionalisasi Variabel

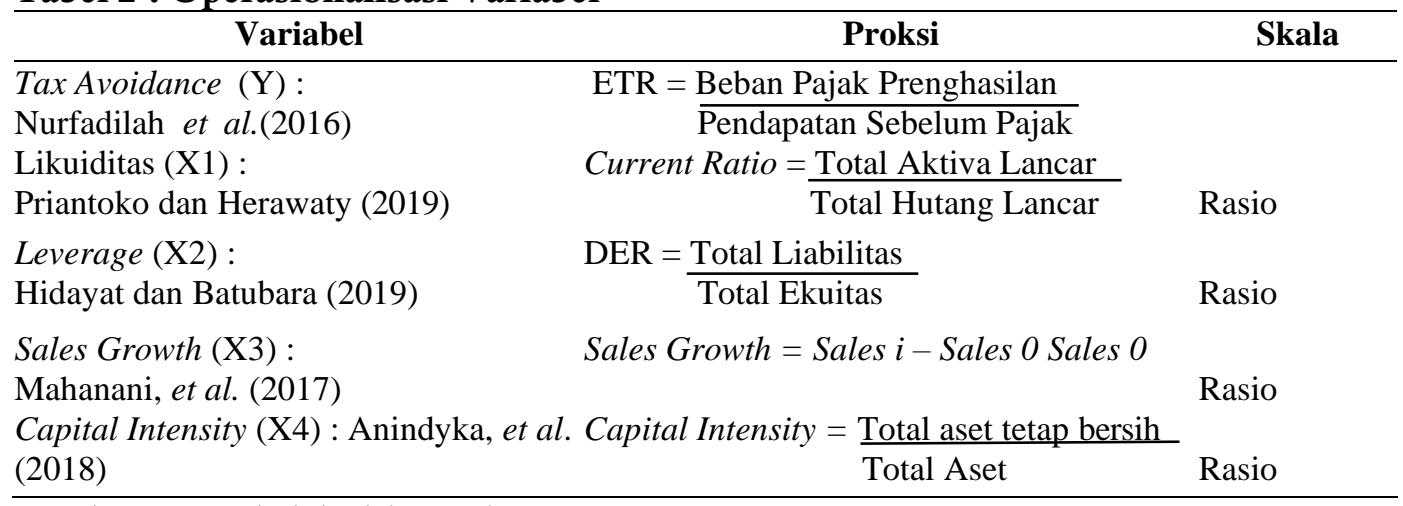

Sumber: Data diolah oleh penulis 
HASIL DAN PEMBAHASAN

Uji Statistik Deskriptif

Tabel 3. Hasil Uji Statistik Deskriptif

\begin{tabular}{|l|l|l|l|l|l|}
\hline & \multicolumn{1}{|c|}{$\begin{array}{c}\text { Tax } \\
\text { Avoidance } \\
\mathbf{Y}\end{array}$} & $\begin{array}{c}\text { Likuiditas } \\
\mathbf{X}_{\mathbf{1}}\end{array}$ & $\begin{array}{c}\text { Leverage } \\
\mathbf{X}_{\mathbf{2}}\end{array}$ & $\begin{array}{c}\text { Sales Growth } \\
\mathbf{X}_{3}\end{array}$ & $\begin{array}{c}\text { Capital } \\
\text { Intensity } \\
\mathbf{X}_{4}\end{array}$ \\
\hline Mean & 0,253151 & 0,3806 & $-0,2684$ & $-1,0530$ & $-0,5247$ \\
\hline Standar Deviasi & 0,0081532 & 0,25437 & 0,33214 & 0,27296 & 0,20432 \\
\hline $\mathrm{N}$ & 120 & 120 & 120 & 120 & 120 \\
\hline
\end{tabular}

Tax Avoidance

and Consumers

Goods

Manufactures

Sumber: Olah data hasil SPSS versi 20.0

Tabel Statistik Deskriptif di atas merupakan bagian yang berisikan penjelasan dan gambaran dari setiap variabel, yaitu sebagai berikut: 1). Variabel Tax Avoidance (Y) mempunyai mean (rata-rata) sebesar 0,253151 dan Std.Deviation (simpangan baku) sebesar 0,0081532 ; 2). Variabel Likuiditas (X1) mempunyai mean (rata-rata) sebesar 0,3806 dan Std.Deviation (simpangan baku) sebesar 0,$25437 ; 3$ ). Variabel Leverage (X2) mempunyai mean (rata-rata) sebesar - 0,2684 dan Std.Deviation (simpangan baku) sebesar 0,33214 ; 4). Variabel Sales Growth (X3) mempunyai mean (rata-rata) sebesar -1,0530 dan Std.Deviation (simpangan baku) sebesar 0,27296; 5). Variabel Capital Intensity (X4) mempunyai mean (rata-rata) sebesar -0,5247 dan Std.Deviation (simpangan baku) sebesar 0,20432 .

Uji Normalitas

Tabel 4. Hasil Analisis Statistik One Sample Kolmogorov Smirnov

\begin{tabular}{|c|c|c|c|}
\hline & & Unstandardized Residual & Kesimpulan \\
\hline Jumlah Data & & 57 & \multirow{8}{*}{$\begin{array}{l}\text { Nilai sig. } 0,502 \\
>0,05 \text { artinya } \\
\text { data } \\
\text { berdistribusi } \\
\text { Normal }\end{array}$} \\
\hline \multirow[t]{2}{*}{ Normal Parameters ${ }^{\mathrm{a}, \mathrm{b}}$} & Mean & 0 & \\
\hline & Std. Deviation & 0,00743454 & \\
\hline \multirow[t]{3}{*}{$\begin{array}{l}\text { Most Extreme } \\
\text { Differences }\end{array}$} & Absolute & 0.109 & \\
\hline & Positive & 0.109 & \\
\hline & Negative & 0.100 & \\
\hline Kolmogorov-Smirnov Z & & 0,827 & \\
\hline Asymp. Sig. (2-tailed) & & 0,502 & \\
\hline
\end{tabular}

Sumber: Olah data hasil SPSS versi 20.0

Untuk uji normalitas peneliti mengalami permasalahan data tidak normal maka dilakukan uji outlier untuk menghasilkan data normal. Setelah melakukan uji outlier maka hasil uji ini menghasilkan output dengan nilai sig sebesar 0,502 , nilai tersebut memenuhi ketentuan sig. (p) 0,502 1>0,05 (level of signification) sehingga hipotesis H0 diterima, sedangkan hipotesis Ha ditolak, munujukan data berdistribusi normal

Uji Multikolinieritas

Tabel 5. Hasil Uji Multikolinearitas

\begin{tabular}{|l|l|c|l|}
\hline \multicolumn{1}{|c|}{ Variabel } & Tolerance & VIF & \multicolumn{1}{c|}{ Kesimpulan } \\
\hline Likuiditas & 0,181 & 5,519 & Tidak terjadi masalah multikolinieritas \\
\hline Leverage & 0,165 & 6,077 & Tidak terjadi masalah multikolinieritas \\
\hline Sales Growth & 0,871 & 1,148 & Tidak terjadi masalah multikolinieritas \\
\hline Capital Intensity & 0,729 & 1,372 & Tidak terjadi masalah multikolinieritas \\
\hline
\end{tabular}

Sumber: Olah data hasil SPSS versi 20.0

Dengan melihat tampilan output Uji Multikolinearitas tabel Coefficients ${ }^{a}$ di atas, diketahui nilai VIF masing-masing variabel sebagai berikut: Likuiditas $=5,519$, Leverage $=6,077$, Sales Growth $=1,148$, Capital Intensity $=1,372$. Dari hasil output di atas diketahui 
Tax Avoidance and juga nilai Tolerance masing-masing variabel sebagai berikut : Likuiditas $=0,181$, Leverage Consumers Goods $\quad=0,165$, Sales Growth $=0,871$, Capital Intensity $=0,729$ dari keempat variabel dapat di Manufactures indikasikan maka tidak terjadi multikolinearitas antar variabel independen.

\section{Uji Heteroskedastisitas}

Pengujian heteroskedastisitas dalam penelitian ini dilakukan dengan uji gletser Tabel 6 Hasil Uji Multikolinieritas

\begin{tabular}{|l|l|l|}
\hline \multicolumn{1}{|c|}{ Variabel } & \multicolumn{1}{c|}{ Signifikan } & \multicolumn{1}{c|}{ Keterangan } \\
\hline Likuiditas & 0,734 & Tidak terjadi heteroskedastisitas \\
\hline Leverage & 0,513 & Tidak terjadi heteroskedastisitas \\
\hline Sales Growth & 0,195 & Tidak terjadi heteroskedastisitas \\
\hline Capital Intensity & 0,215 & Tidak terjadi heteroskedastisitas \\
\hline
\end{tabular}

Sumber: Olah data hasil SPSS versi 20.0

Berdasarkan hasil uji glejser di atas pada tabel 6 menunjukkan bahwa semua variabel independen dipenelitian ini memiliki nilai signifikan $>0.05$. Likuiditas memiliki nilai signifikan 0.734 , leverage 0.513 , sales growth 0.195 dan capital intensity 0.215 . Dengan hasil tersebut dapat disimpulkan bahwa data penelitian tidak terjadi heteroskedastisitas.

Uji Autokorelasi

Tabel 6 Uji Durbin-Watson

\begin{tabular}{|l|c|l|l|l|l|}
\hline Model & $\mathbf{R}$ & $\mathbf{R}$ Square & Adjusted R Square & $\begin{array}{c}\text { Std. Error of the } \\
\text { Estimate }\end{array}$ & Durbin-Watson \\
\hline 1 &, $411^{\mathrm{a}}$ &, 169 &, 105 &, 0077152 & 2,142 \\
\hline
\end{tabular}

Sumber: Data diolah sendiri (2019)

Berdasarkan hasil uji Durbin-Watson (DW) di atas diperoleh nilai sebesar 2.142. Dari tabel DW dengan didapatkan nilai batas atas (dU) sebesar 1.7253 dan nilai batas bawah (dL) sebesar 1.4264. Dalam analisis uji autokorelasi ini menunjukkan dU (1.7253) $<$ DW $(2.142)<4-$ dU (1.7253), dimana dapat disimpulkan bahwa tidak adanya autokorelasi.

Uji Persamaan Regresi

Tabel 7. Hasil Analisis Regresi Linear Berganda

\begin{tabular}{|l|l|l|l|l|}
\hline \multicolumn{1}{|c|}{ Variabel } & \multicolumn{1}{c|}{ Koefisien } & t-hitung & \multicolumn{1}{c|}{ Sig. } & \multicolumn{1}{c|}{ Kesimpulan } \\
\hline (Constant) & 0,263 & 50,702 & 0,000 & Tidak Signifikan \\
\hline Likuiditas & -0.004 & $-0,415$ & 0,680 & Tidak Signifikan \\
\hline Leverage & 0.004 & 0,535 & 0,595 & Tidak Signifikan \\
\hline Sales Growth & 0.009 & 2,102 & 0.040 & Signifikan \\
\hline Capital Intensity & -0.004 & $-0,709$ & 0.482 & Tidak Signifikan \\
\hline
\end{tabular}

Sumber: Olah data hasil SPSS versi 20.0

Dengan melihat tampilan output Analisis Regresi Linear Berganda tabel coefficients ${ }^{a}$ di atas, maka persamaan regresi yang didapat yaitu sebagai berikut:

$$
Y=0,263-0,004\left(X_{1}\right)+0,004\left(X_{2}\right)+0,009\left(X_{3}\right)-0,004\left(X_{4}\right)+\varepsilon
$$

\section{Analisis Koefisien Determinasi (Uji $\mathbf{R}^{2}$ )}

Tabel 8. Hasil Koefisien Determinasi

\begin{tabular}{|l|l|l|l|l|l|}
\hline Model & R & R Square & $\begin{array}{l}\text { Adjusted } \\
\text { R Square }\end{array}$ & $\begin{array}{l}\text { Std. Error of } \\
\text { the Estimate }\end{array}$ & \multicolumn{1}{c|}{ Kesimpulan } \\
\hline 1 & $0.411^{\mathrm{a}}$ & 0,169 & 0.105 & 0.0077152 & $\begin{array}{l}\text { Persentase kontribusi variabel } \\
\text { independend terhadap terhadap } \\
\text { variabel dependend sebesar } 10,5 \%\end{array}$ \\
\hline
\end{tabular}

Sumber: Olah data hasil SPSS versi 20.0

Dengan melihat tampilan output analisis koefisien determinasi tabel Model Summary ${ }^{b}$ Adjusted $R$ Square sebesar 0,105 atau (10,5\%). Koefisien ini menunjukkan bahwa sebesar 
10,5\% dari nilai Tax Avoidance perusahaan barang konsumsi ditentukan oleh (Likuiditas, Leverage, Sales Growth dan Capital Intensity) sedangkan sisanya (89.5\%), (100\% - 10,5\%) faktor lain diluar dari variabel yang sudah diteliti.

Uji Kelayakan Model (Uji F)

Tabel 9. Hasil Kelayakan Model (Uji F)

\begin{tabular}{|l|l|l|l|l|}
\hline \multicolumn{1}{|c|}{ Model } & \multicolumn{1}{c|}{ Df } & \multicolumn{1}{c|}{ F-Hitung } & \multicolumn{1}{c|}{ Sig } & Kesimpulan \\
\hline Regression & 4 & 2,635 & 0,44 & Model Layak \\
\hline Residual & 0,003 & & & \\
\hline Total & 0,004 & & & \\
\hline
\end{tabular}

Sumber: Olah data hasil SPSS versi 20.0

Berdasarkan tabel di atas dapat diketahui nilai signifikannya $0.044<0.05$. Maka H0 ditolak dan H1 diterima, yang berarti bahwa model dianggap layak atau fit dan dapat dijadikan model dipenelitian ini.

\section{Interpretasi Hasil Penelitian}

\section{Pengaruh Likuiditas Terhadap Tax Avoidance}

Secara parsial Likuiditas tidak memiliki pengaruh terhadap tax avoidance.Perusahaan yang memiliki tingkat likuiditas yang rendah menggambarkan bahwa perusahaan memiliki arus kas yang buruk. Namun arus kas yang buruk tidak dapat memberi pengaruh yang cukup besar pula dalam mengurangi pembayaran pajak yang dilakukan perusahaan. Karena pada dasarnya arus kas perusahaan yang kecil bukan semata-mata perusahaan selalu menghindari pajak, beberapa perusahaan mampu menepati membayar pajakanya walaupun keadaan arus kasnya tidak baik.Hasil penelitian ini konsisten dengan penelitian sebelumnya yaitu Hasil penelitian ini konsisten dengan penelitian Ariani dan Hasyim (2018) yang menunjukkan bahwa likuiditas tidak berpengaruh terhadap tax avoidance.

\section{Pengaruh Leverage Terhadap Tax Avoidance}

Hasil analisis ini menunjukkan bahwa variabel leverage tidak mempunyai pengaruh terhadap tax avoidance. Hal ini dikarenakan Leverage bagi suatu perusahaan adalah pendanaan untuk memenuhi kebutuhan dalam kegiatan operasioanal perusahaan dan memanfaatkan pendanaan berupa hutang. Namun tingginya leverage tidak memiliki pengaruh yang cukup tinggi pula bagi perusahaan dalam meminimalisir pembayaran pajak yang dilakukan. Salah satu penyebab leverage tidak berpengaruh terhadap tax avoidance adalah munculnya beban bunga sebagai pengurang laba kena pajak akibat munculnya hutang. Beban bunga yang muncul akibat adanya pinjaman perusahaan kepada pihak ketiga yang tidak berkaitan dengan perusahaan, hal tersebut yang menyebabkan beban bunga sebagai pegurang laba kena pajak. Hasil penelitian ini konsisten dengan penelitian yang dilakukan Dewinta dan Setiawan (2016) dan Cahyono et al. (2016) yang menunjukkan bahwa leverage tidak berpengaruh terhadap tax avoidance.

\section{Pengaruh Sales Growth Terhadap Tax Avoidance}

Hasil analisis data menunjukkan bahwa $\mathrm{H}_{3}$ diterima, ini mengartikan bahwa variabel sales growth berpengaruh positif dan signifikan terhadap tax avoidance. Perusahaan dengan sales growth yang tinggi menggambarkan bahwa perusahaan mendapatkan keuntungan yang besar, oleh karena itu perusahaan akan menimbulkan beban pajak yang besar pula. Besarnya beban pajak yang ditimbulkan dari tingginya tingkat penjualan menyebabkan perusahaan memiliki kecenderungan yang besar untuk melakukan tax avoidance agar pajak yang dibayarkan berkurang. Sebagaimana yang dijelaskan dalam teori agensi bahwa agen akan melakukan sesuatu untuk kepentingannya sendiri. Oleh karena itu perusahaan yang memiliki sales growth yang tinggi memiliki kecenderungan yang besar untuk melakukan tax avoidance. Hasil penelitian ini konsisten dengan penelitian yang dilakukan oleh Dewinta dan Setiawan (2016) yang menunjukkan bahwa sales growth berpengaruh positif dan signifikan terhadap tax avoidance.

\section{Pengaruh Capital Intensity Terhadap Tax Avoidance}

Tax Avoidance

and Consumers

Goods

Manufactures 
Tax Avoidance and Consumers Goods Manufactures
Hasil analisis menunjukan capital intensity tidak berpengaruh terhadap tax avoidance. Capital intensity diartikan seberapa besar perusahaan menginvestasikan kekayaannya terhadap aset tetap. Sebagian besar pasti mengalami penyusutan yang member pengaruh berkurangnya pajak yang harus dibayarkan. Tetapi pada kenyataanya besarnya kepemilikan aset tetap dalam perusahaan tidak dapat memberi pengaruh yang cukup besar dalam hal mengurangi pembayaran pajak. Dikarenakan dasarnya jumlah aset tetap yang besar bukan hanya untuk menghindari pajak, melainkan hal tersebut dilakukan dengan maksud untuk menunjang kegiatan perusahaan untuk menyediakan barang serta jasa dengan tujuan untuk kepentingan perusahaan. Hasil penelitian ini konsisten dengan penelitian Wiguna dan Jati (2017) yang membuktikan bahwa capital intensity tidak berpengaruh terhadap tax avoidance.

\section{PENUTUP}

Penelitian ini bertujuan untuk mengetahui pengaruh likuiditas, leverage, sales growth dan capital intensity terhadap tax avoidance. Terdapat 120 sampel data yang digunakan dari 24 perusahaan sub sektor barang konsumsi yang terdaftar di Bursa Efek Indonesia (BEI) selama periode 2014 sampai dengan 2018. Hasil analisis dapat disimpulkan dimana likuiditas, leverage dan capital intensity tidak berpengaruh terhadap tax avoidance. Sedangkan sales growth berpengaruh positif terhadap tax avoidance.

\section{DAFTAR PUSTAKA}

Adita, A., \& Mawardi, W. (2018). Pengaruh Struktur Modal, Total Assets Turnover, dan Likuiditas terhadap Nilai Perusahaan dengan Profitabilitas sebagai Variabel Intervening (Studi Empiris pada Perusahaan Real Estate dan Properti yang Terdaftar di BEI Periode 2013-2016). Jurnal Studi Manajemen Organisasi, 15(1), 2943

Anindyka S, Dimas., Dudi Pratomo dan Kurnia. (2018). Pengaruh Leverage (DAR), Capital Intensity dan Inventory Intensity terhadap Tax Avoidance (Studi pada Perusahaan Makanan dan Minuman di Bursa Efek Indonesia (BEI) tahun 2011 2015). e-Proceeding of Management, 5(1).

Anita, Fitri M. (2015). Pengaruh Corporate Social Responsibility, Leverage, Likuiditas dan Ukuran Perusahaan Terhadap Agresivitas Pajak (Studi Empiris Pada Perusahaan Real Estate dan Property yang Terdaftar di BEI Tahun 2010-2013). Jom Fekon., 2.

Ariani, Miza dan Hasyim, Mhd. (2018). Pengaruh Proditabilitas, Likuiditas, Leverage, Size dan Capital Intensity Ratio Terhadap Effective Tax Rate (ETR). Profita : Komunikasi Ilmiah Akuntansi dan Perpajakan, 11.

Budianti, Shinta dan Curry, Khirstina. (2018). Pengaruh Profitabilitas, Likuiditas dan Capital Intensity Terhadap Penghindaran Pajak (Tax Avoidance). Seminar Nasional Cendikiawan ke 4 tahun 2018.

Cahyono, Deddy Dyas, Rita Andini dan Kharis Raharjo. (2016). Pengaruh Komite Audit, Kepemilikan Institusional, Dewan Komisaris, Ukuran Perusahaan (Size), Leverage (DER) dan Profitabilitas (ROA) Terhadap Tindakan Penghindaran Pajak (Tax Avoidance) Pada Perusahaan Perbankan yang Listing di BEI Periode Tahun 2011-2013. Journal of Accounting, 2.

Darmawan, I. G. H., \& Sukartha, I. M. (2014). Pengaruh Penerapan Corporate Governance, Leverage, Return On Assets, dan Ukuran Perusahaan pada Penghindaran Pajak. EJurnal Akuntansi Universitas Udayana 9.1.

Dewinta, Ida Ayu Rosa dan Putu Ery Setiawan. (2016) Pengaruh Ukuran Perusahaan, Umur Perusahaan, Profitabilitas, Leverage dan Pertumbuhan Penjualan Terhadap Tax Avoidance. E-Jurnal Akuntansi Universitas Udayana, 14. 
Dharma, Nyoman Budhi Setya dan Naniek Noviari. (2017). Pengaruh Corporate Social Responsibility dan Capital Intensity terhadap Tax Avoidance. E- jurnal Akuntansi Universitas Udayana, 18(1).

Anggreani, S., \& Adnyana, I. G. S. (2020). Penentuan Harga Pokok Produksi Dengan Metode Full Costing Sebagai Dasar Penetapan Harga Jual Pada UKM Tahu AN Anugrah. Jurnal Ilmiah Akuntansi Kesatuan, 8(1), 9-16.

Djanegara, M. S., Mulyani, S., Putra, D. M., Zahra, N. A. K., \& Mauludina, M. A. (2018). The effect of institutionalization isomorphic pressures and the role of knowledge management on investment decisions of the accounting information systems. Polish Journal of Management Studies, 18.

Herjanti, S., \& Teg, I. W. T. (2020). Analisis Efektivitas dan Laju Pertumbuhan Pajak Daerah serta Kontribusinya Terhadap Pendapatan Asli Daerah Di Kota Bogor Periode 2013-2017. Jurnal Ilmiah Akuntansi Kesatuan, 8(1), 37-48.

Hery.2015. AnalisisLaporan Keuangan. Edisi 1. Yogyakarta: Center For Academic Publishing Services.

Iriyadi, I., Tartilla, N., \& Gusdiani, R. (2020, May). The Effect of Tax Planning and Use of Assets on Profitability with Good Corporate Governance as a Moderating Variable. In 2nd International Seminar on Business, Economics, Social Science and Technology (ISBEST 2019) (pp. 220-227). Atlantis Press.

Jensen, M., C., dan W. Meckling, 1976. "Theory of the firm: Managerial behavior, agency cost and ownership structure", Journal of Finance Economic 3:305-360, didownload dari http://www.nhh.no/for/courses/spring/eco420/jensen-meckling76.pdf

Khairunnisa, N., \& Yuliandi, Y. (2019). Compliance Audit Sebagai Alat Untuk Mendorong Tercapainya Tujuan Organisasi (Studi kasus pada Hotel The 101 Suryakencana Bogor). Jurnal Ilmiah Akuntansi Kesatuan, 7(2), 310-317.

Kasmir. 2017. Analisis Laporan Keuangan. Depok: PT Raja Grafindo Persada.

Kimsen ; Kismanah, Imas ; Masitoh, Siti. (2018). Profitability, Leverage, Size of Company Toward Tax Avoidance. Jurnal Ilmiah Akuntansi Fakultas Ekonomi, 4.

Kesuma, Ali. 2009. Analisis Faktor yang Mempengaruhi Struktur Modal Serta Pengaruhnya Terhadap Harga Saham Perusahaan Real Estate yang Go Public di Bursa Efek Indonesia, Jurnal Manajemen dan Kewirausahaan, Vol 11, No1, Maret 2009, 38-45.

Mahardika, A. G., Pramiudi, U., \& Fahmi, A. (2019). Peranan Penerapan Sistem Akuntansi Accurate Terhadap Penyusunan Laporan Keuangan (Studi Kasus Pada Umkm Toko Textile Leuwi Di Bogor). Jurnal Ilmiah Akuntansi Kesatuan, 7(1), 193196.

Nugroho, A. D. (2009). Anti Avoidance Rules di Indonesia Pasca Amandemen UU Pajak Penghasilan. Jurnal Fakultas Hukum, 21(1).

Nurfadilah et al., 2016. Pengaruh Leverage, Ukuran Perusahaan dan Kualitas Audit, Terhadap Penghindaran Pajak. Syariah Paper Accounting FEB Universitas Muhammadyah Surakarta.Surakarta

Pamungkas, B., Flassy, D. A., Yudanto, S., Rachman, H. A., Rahayu, S., Komarudin, S., \& Setijono, H. (2018). Accrual-based accounting implementation in Indonesian's local governments compared to other countries' experiences. Man in India, 98(1), 1-23.

Permata, Amanda Dhinari., Siti Nurlaela dan Endang Masitoh W. (2018). Pengaruh Size, Age, Profitability, Leverage dan Sales Growth terhadap Tax Avoidance. Jurnal Akuntansi dan Pajak Universitas Islam Batik Surakarta, 19(1).

Pohan, Chairil Anwar. 2016. Manajemen Perpajakan Strategi Perencanaan Pajak dan Bisnis . Jakarta : PT. Gramedia Pustaka Utama.

Rachman, R. (2019). Analisa Pengendalian Piutang Terhadap Resiko Piutang Tak tertagih Pada PT. Enseval Putera Megatrading Tbk Cabang Bogor. Jurnal Ilmiah Akuntansi Kesatuan, 7(3), 343-350.

Tax Avoidance and

Consumers Goods Manufactures 
Tax Avoidance and Roup, A. (2019). Evaluasi Sistem Informasi Akuntansi Pembelian Dalam Kaitannya Consumers Goods Manufactures Dengan Pengendalian Internal. Jurnal Ilmiah Akuntansi Kesatuan, 7(1), 187-192.

Salaudeen, Yinka Mashood dan Uchenna Celestine Eze. (2018). Firm Specific Determinants of Corporate Effective Tax Rate of Listed Firm in Nigeria. Journal of Accounting and Taxation, 10.

Subagja, R., \& Pradipto, D. (2019). Analisis Penerapan Pengakuan Pendapatan Kontrak Konstruksi Berdasarkan PSAK 34. Jurnal Ilmiah Akuntansi Kesatuan, 7(3), 391-396.

Undang-Undang Nomor 16 tahun 2009 tentang perubahan keempat atas UndangUndang Nomor 6 tahu 1983 tentang Ketentuan Umum dan Tata Cara Perpajakan.

Wiguna, I Putu Putra dan I Ketut Jati. (2017). Pengaruh Corporate Social Responsibility, Preferensi Risiko Eksekutif, dan Capital Intensity pasa Penghindaran Pajak. E-Jurnal Akuntansi Universitas Udayana, 21(1).

https://www.bisnis.liputan6.com

https://www.money.kompas.com 